Article

\title{
Alpha-Glucosidase Inhibition and Molecular Docking of Isolated Compounds from Traditional Thai Medicinal Plant, Neuropeltis racemosa Wall.
}

\author{
Oraphan Sakulkeo ${ }^{1}$, Chatchai Wattanapiromsakul ${ }^{1}$, Thanet Pitakbut ${ }^{2}$ D and Sukanya Dej-adisai ${ }^{1, *}$ \\ 1 Department of Pharmacognosy and Pharmaceutical Botany, Faculty of Pharmaceutical Sciences, \\ Prince of Songkla University, Hat Yai 90112, Songkhla, Thailand; oraphan.s@psu.ac.th (O.S.); \\ chatchai.w@psu.ac.th (C.W.) \\ 2 Department of Biochemical and Chemical Engineering, Technical University of Dortmund, \\ 44227 Dortmund, Germany; thanet.pitakbut@tu-dortmund.de \\ * Correspondence: sukanya.d@psu.ac.th; Tel.: +66-74-288-888; Fax: +66-74-288-891
}

check for

updates

Citation: Sakulkeo, O.;

Wattanapiromsakul, C.; Pitakbut, T.; Dej-adisai, S. Alpha-Glucosidase Inhibition and Molecular Docking of Isolated Compounds from Traditional Thai Medicinal Plant, Neuropeltis racemosa Wall. Molecules 2022, 27, 639. https://doi.org/ $10.3390 /$ molecules 27030639

Academic Editors: Simona Fabroni, Krystian Marszałek and Aldo Todaro

Received: 29 December 2021

Accepted: 17 January 2022

Published: 19 January 2022

Publisher's Note: MDPI stays neutral with regard to jurisdictional claims in published maps and institutional affiliations.

Copyright: (C) 2022 by the authors. Licensee MDPI, Basel, Switzerland. This article is an open access article distributed under the terms and conditions of the Creative Commons Attribution (CC BY) license (https:// creativecommons.org/licenses/by/ $4.0 /)$.

\begin{abstract}
Neuropeltis racemosa Wall. (Convolvulaceae) is wildly distributed in Asia. Its stem is used as the component in traditional Thai recipes for treatments of muscle rigidity, skin disorder, dysentery, and hypoglycemia. However, the chemical constituents and biological activities of N. racemosa have not been reported. From a screening assay, N. racemosa stem crude extract showed the potent effect on alpha-glucosidase inhibition at $2 \mathrm{mg} / \mathrm{mL}$ as $96.09 \%$. The bioassay-guiding isolation led to 5 compounds that were identified by spectroscopic techniques as scopoletin (1), syringic acid (2), methyl 3-methyl-2-butenoate (3), $N$-trans-feruloyltyramine (4), and $N$-trans- coumaroyltyramine (5). Compounds 1, 4, and 5 exhibited an $\mathrm{IC}_{50}$ of $110.97,29.87$, and $0.92 \mu \mathrm{g} / \mathrm{mL}$, respectively, while the $\mathrm{IC}_{50}$ of positive standard, acarbose was $272.72 \mu \mathrm{g} / \mathrm{mL}$. Kinetic study showed that compound 1 performed as the mixed-type inhibition mechanism, whereas compounds $\mathbf{4}$ and $\mathbf{5}$ displayed the uncompetitive inhibition mechanism. The docking study provided the molecular understanding of isolated aromatic compounds (1, 2, 4 and 5) to alpha-glucosidase. Hence, this study would be the first report of isolated compounds and their anti-alpha-glucosidase activity with the mechanism of action from N. racemosa. Thus, these active compounds will be further studied to be the lead compounds among natural antidiabetic drugs.
\end{abstract}

Keywords: Neuropeltis racemosa; alpha-glucosidase inhibition; anti-diabetes; phytochemistry; molecular docking

\section{Introduction}

Diabetes mellitus (DM) is metabolic syndrome related to a hyperglycemia condition. In 2021, The International Diabetes Federation reported number of diabetes adults is 537 million and the trend will rise to 783 million in 2045 [1]. Two major diabetic types are type 1 diabetes (insulin defection from the problem of beta cells) and type 2 diabetes (insulin resistance from the inability of body cells). Patients of both types have a blood glucose uncontrollable condition. Exogenous insulin is considered in patients with type 1 diabetes, while many classes of glucose-lowering agents are used for patients with type 2 diabetes [2] Although many clinical compounds are available, drugs used in the management of DM are complicated [3]. Therefore, new drug development for diabetes is ongoing. Folk medicine is the alternative treatment that provides sources of interesting herbal medicine. The medicinal plants were investigated for their potential ability using in vitro bioactivitytargeted screening.

Neuropeltis racemosa Wall. (Convolvulaceae) is wildly distributed in Asian countries such as China, Myanmar, Malaysia, Indonesia [4], and including many regions of Thailand. The stem of $N$. racemosa is used as a component of traditional Thai recipes for treatments 
of muscle rigidity, skin disorder, dysentery, and hypoglycemia [5-7]. N. racemosa is also used as a component of Mathurameha (traditional Thai recipe) that has been reported in regards to hypoglycemic activity [6]. It agreed with our preliminary screening assay, as the methanolic extract of $N$. racemosa stem showed the potent effect of alpha-glucosidase inhibition at $2 \mathrm{mg} / \mathrm{mL}$ as $96.09 \%$. Nowadays, the study of N. racemosa remains poor. Therefore, $N$. racemosa stem was selected for an investigation of chemical constituents, alpha-glucosidase inhibition, mode of action, and a molecular docking study.

\section{Results}

\subsection{Determination of Alpha-Glucosidase Inhibition}

The stem of $N$. racemosa was extracted with different solvent by increasing the polarity from $n$-hexane, EtOAc, EtOH, and water, respectively. Four solvent extracts were determined on alpha-glucosidase inhibitory activity. $n$-Hexane, EtOAc, $\mathrm{EtOH}$, and water extracts exhibited alpha-glucosidase inhibition with an $\mathrm{IC}_{50}$ of $56.81 \mathrm{~g} / \mathrm{mL}, 191.44 \mu \mathrm{g} / \mathrm{mL}$, $39.65 \mu \mathrm{g} / \mathrm{mL}$, and $4.02 \mathrm{mg} / \mathrm{mL}$, respectively, while the standard, acarbose exhibited an $\mathrm{IC}_{50}$ of $245.95 \mu \mathrm{g} / \mathrm{mL}$. Therefore, EtOH extract showed the highest inhibition effect towards the alpha-glucosidase enzyme.

\subsection{Extraction, Isolation, and Identification of Pure Compounds}

From the bioactivity-guided isolation of the $N$. racemose stem, the EtOH extract was selected to isolate pure compounds by chromatographic techniques. Five pure compounds (1-5) were isolated and identified as scopoletin (1), syringic acid (2), methyl 3-methyl-2butenoate (3), $\mathrm{N}$-trans-feruloyltyramine (4), and $\mathrm{N}$-trans-coumaroyltyramine (5) (Figure 1).<smiles>COc1[12cH]c2ccc(=O)oc2cc1O</smiles>

1<smiles>COc1cc(C(=O)O)cc(OC)c1O</smiles>

2<smiles>COC(=O)C=C(C)C</smiles>

3<smiles>COc1cc(/C=C/C(=O)NCCc2ccc(O)cc2)ccc1O</smiles>

Figure 1. Isolated compounds (1-5) from $N$. racemosa stem.

\subsubsection{Scopoletin (1)}

Compound $\mathbf{1}$ was obtained as yellow pale needles and dissolved in chloroform. The UV spectrum in chloroform showed an absorption maximum $\left(\lambda_{\max }\right)$ at $341 \mathrm{~nm}$. The IR spectrum demonstrated maximum absorption bands at 3460,1651, 1218, 772, and $669 \mathrm{~cm}^{-1}$. The ${ }^{1} \mathrm{H}-\mathrm{NMR}$ spectrum of 1 exhibited six proton signals. The two doublet signals at $\delta_{\mathrm{H}}$ $6.25(1 \mathrm{H}, \mathrm{d}, J=9.5 \mathrm{~Hz}, \mathrm{H}-3)$ and $7.58(1 \mathrm{H}, \mathrm{d}, J=9.5 \mathrm{~Hz}, \mathrm{H}-4)$ were determined as olefinic protons. The others are four singlet signals. Two of four singlet signals at $\delta_{\mathrm{H}} 6.63(1 \mathrm{H}, \mathrm{s}$, $\mathrm{H}-6)$ and $6.90(1 \mathrm{H}, \mathrm{s}, \mathrm{H}-9)$ belong to aromatic proton. The signal at $\delta_{\mathrm{H}} 6.17(1 \mathrm{H}, \mathrm{s}, \mathrm{OH}-8)$ was determined as the hydroxyl proton, while the signals at $\delta_{\mathrm{H}} 3.94\left(3 \mathrm{H}, \mathrm{s}, \mathrm{OCH}_{3}-7\right)$ was assigned as methoxyl proton. The ${ }^{13} \mathrm{C}-\mathrm{NMR}$ spectrum showed ten carbon signals that were observed: three oxygenated aromatic carbon signals at $\delta_{C} 143.96$ (C-7),149.64 (C-8) and 150.23 (C-10); two tertiary aromatic carbon signals at $\delta_{C} 103.18$ (C-9) and 107.44 (C-6); two olefinic methine signals at $\delta_{C} 113.42(\mathrm{C}-3)$ and 143.29 (C-4); one quaternary carbon signals at $\delta_{C} 111.48(\mathrm{C}-5)$; one carbonyl signal at $\delta_{C} 161.43$ (C-2), and one methoxyl signal 
at $\delta_{\mathrm{C}} 56.39\left(\mathrm{OCH}_{3}-7\right)$. The molecular formula of $\mathbf{1}$ is $\mathrm{C}_{10} \mathrm{H}_{8} \mathrm{O}_{4}$. The HMBC correlations (Figure 2) were used for confirming the structure substitution. The NOESY experiment of 1 showed the correlation signal between the proton of C-6 and the methoxyl proton of C-7. As mentioned above, it was suggested that compound $\mathbf{1}$ is a scopoletin that is different from iso-scopoletin [8].

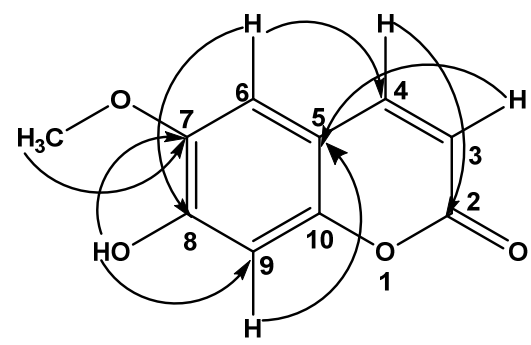

Figure 2. HMBC correlations (from $\mathrm{H}$ to $\mathrm{C}$ ) of compound 1.

\subsubsection{Syringic Acid (2)}

Compound 2 was obtained as an orange amorphous solid and dissolved in methanol. The UV spectrum in methanol demonstrated an absorption maximum $\left(\lambda_{\max }\right)$ at $289 \mathrm{~nm}$. The IR spectrum exhibited bands at 3434, 1634, and $1426 \mathrm{~cm}^{-1}$. The ${ }^{1} \mathrm{H}-\mathrm{NMR}$ spectrum of 2 exhibited three singlet proton signals. The singlet signal at $\delta_{\mathrm{H}} 3.78\left(6 \mathrm{H}, \mathrm{s}, \mathrm{OCH}_{3}-3\right.$ and $\mathrm{OCH}_{3}-5$ ) was assigned as two methoxyl proton signals, while the singlet signal at $\delta_{\mathrm{H}} 7.19$ $(2 \mathrm{H}, \mathrm{s}, \mathrm{H}-2$ and $\mathrm{H}-6)$ was determined as aromatic protons. The last broad singlet signal at $\delta_{\mathrm{H}} 9.07(1 \mathrm{H}, \mathrm{br}, \mathrm{COOH}-1)$ was defined as the carboxylic proton. The HR-ESIMS showed an $[\mathrm{M}-\mathrm{H}]^{-}$ion peak at $m / z 197.0456$, and correlated with a molecular formula of $\mathrm{C}_{9} \mathrm{H}_{10} \mathrm{O}_{5}$. The structure of $\mathbf{2}$ was determined to be syringic acid.

\subsubsection{Methyl 3-Methyl-2-butenoate (3)}

Compound 3 was obtained as a brown amorphous solid and dissolved in chloroform. The UV spectrum in chloroform demonstrated an absorption maximum $\left(\lambda_{\max }\right)$ at $290 \mathrm{~nm}$. The IR spectrum exhibited band at 2922, 1698-1595, 1457, 1260-1220, 1110, and $874-800 \mathrm{~cm}^{-1}$. The ${ }^{1} \mathrm{H}-\mathrm{NMR}$ spectrum showed three singlet proton signals at $\delta_{\mathrm{H}} 1.2(6 \mathrm{H}, \mathrm{s}$, $\mathrm{CH}_{3}-3$ and $\left.\mathrm{H}-4\right), 3.8\left(3 \mathrm{H}, \mathrm{s}, \mathrm{OCH}_{3}-1\right)$, and $5.8(1 \mathrm{H}, \mathrm{s}, \mathrm{H}-2)$. The ${ }^{13} \mathrm{C}-\mathrm{NMR}$ spectrum showed six carbon signals that were observed: one quaternary carbon signal at $\delta_{C} 157.30(C-3)$; one olefinic methine signal at $\delta_{C} 107.42(\mathrm{C}-2)$; one carbonyl signal at $\delta_{C} 186.84(\mathrm{C}-1)$; one methoxyl signal at $\delta_{\mathrm{C}} 56.48\left(\mathrm{OCH}_{3}-1\right)$, and two methyl signals at $\delta_{\mathrm{C}} 29.69(\mathrm{C}-4)$ and at $\delta_{\mathrm{C}} 29.35\left(\mathrm{CH}_{3}-3\right)$. The HMBC correlations (Figure 3$)$ suggested the substitution of 3 . The structure of 3 was elucidated as methyl 3-methyl-2-butenonoate.<smiles>COC(=O)C1=C(C)CCC2CCCCCCCC12</smiles>

Figure 3. HMBC correlations (from $\mathrm{H}$ to $\mathrm{C}$ ) of compound 3.

\subsubsection{N-trans-Feruloyltyramine (4)}

Compound 4 was obtained as a white amorphous solid and dissolved in methanol. The UV spectrum in methanol showed an absorption maximum $\left(\lambda_{\max }\right)$ at $318 \mathrm{~nm}$. The IR spectrum demonstrated band at 3434, 1652, 1542, and $978 \mathrm{~cm}^{-1}$. The ${ }^{1} \mathrm{H}-\mathrm{NMR}$ spectrum exhibited the methoxyl proton signal at $\delta_{\mathrm{H}} 3.78\left(3 \mathrm{H}, \mathrm{s}, \mathrm{OCH}_{3}-6\right)$. The two doublets at $\delta_{\mathrm{H}}$ $6.39(1 \mathrm{H}, \mathrm{d}, J=15.62 \mathrm{~Hz}, \mathrm{H}-2)$ and $7.42(1 \mathrm{H}, \mathrm{d}, J=15.62 \mathrm{~Hz}, \mathrm{H}-3)$ indicated the presence of two trans protons. The two doublet of doublet signals at $\delta_{\mathrm{H}} 3.45(2 \mathrm{H}, \mathrm{dd}, J=7.08$ and 
$\left.7.56 \mathrm{~Hz}, \mathrm{H}-1^{\prime}\right)$ and $2.75\left(2 \mathrm{H}, \mathrm{dd}, J=7.08\right.$ and $\left.7.56 \mathrm{~Hz}, \mathrm{H}-2^{\prime}\right)$ were determined as methylene protons which conjugated to secondary amine and aromatic parts, respectively. The residue five proton signals at $\delta_{\mathrm{H}} 6.72\left(2 \mathrm{H}, \mathrm{dd}, J=9.27\right.$ and $2.40 \mathrm{~Hz}, \mathrm{H}-5^{\prime}$ and $\left.\mathrm{H}-7^{\prime}\right), 6.78(1 \mathrm{H}, \mathrm{d}$, $J=8.06 \mathrm{~Hz}, \mathrm{H}-8), 7.01(1 \mathrm{H}, \mathrm{dd}, J=8.29$ and $1.95 \mathrm{~Hz}, \mathrm{H}-9), 7.05(2 \mathrm{H}, \mathrm{dd}, J=9.27$ and $2.40 \mathrm{~Hz}$, $\mathrm{H}-4^{\prime}$ and $\left.\mathrm{H}-8^{\prime}\right)$, and $7.11(1 \mathrm{H}, \mathrm{d}, J=1.95 \mathrm{~Hz}, \mathrm{H}-5)$ were indicated as seven aromatic protons of two aromatic rings. The ${ }^{13} \mathrm{C}$ NMR showed sixteen carbon signals; however, they were indicated as eighteen carbons: carbonyl carbon at $\delta_{C} 169.19$ (C-1); the methoxyl carbon $\delta_{\mathrm{C}} 56.42\left(\mathrm{OCH}_{3}-6\right)$; two methylene carbons at $\delta_{\mathrm{C}} 35.81\left(\mathrm{C}-2^{\prime}\right)$ and $42.53\left(\mathrm{C}-1^{\prime}\right)$; two olefinic methine carbon at $\delta_{\mathrm{C}} 118.79(\mathrm{C}-2)$ and 142.01 (C-3); two quaternary aromatic carbon at $\delta_{\mathrm{C}} 128.31(\mathrm{C}-4)$ and $131.22\left(\mathrm{C}-3^{\prime}\right)$; three oxygenated aromatic carbons at $\delta_{\mathrm{C}} 149.32(\mathrm{C}-6)$, $149.88(\mathrm{C}-7)$ and $156.94\left(\mathrm{C}-6^{\prime}\right)$; five tertiary aromatic carbons at $\delta_{\mathrm{C}} 111.63(\mathrm{C}-5), 116.42(\mathrm{C}-8)$, 123.22 (C-9) $130.72\left(\mathrm{C}-4^{\prime}\right.$ and C-8'), and 116.28 (C-5' and C-7'). The HR-ESIMS showed an $[\mathrm{M}+\mathrm{Na}]^{+}$ion peak at $m / z 336.1206$ (calcd. for $\left[\mathrm{C}_{18} \mathrm{H}_{19} \mathrm{NO}_{4}+\mathrm{Na}{ }^{+}\right.$), correlated with a molecular formula of $\mathrm{C}_{18} \mathrm{H}_{19} \mathrm{NO}_{4}$. The structure of $\mathbf{4}$ was determined to be $\mathrm{N}$-transferuloyltyramine.

\subsubsection{N-trans-Coumaroyltyramine (5)}

Compound 5 was obtained as a white amorphous solid and dissolved in methanol. The UV spectrum in methanol showed an absorption maximum $\left(\lambda_{\max }\right)$ at $295 \mathrm{~nm}$. The IR spectrum demonstrated a band at 3434,1637, 1541, and $980 \mathrm{~cm}^{-1}$. The ${ }^{1} \mathrm{H}$ spectrum of 5 showed doublet signals at $\delta_{\mathrm{H}} 6.38(1 \mathrm{H}, \mathrm{d}, J=15.86 \mathrm{~Hz}, \mathrm{C}-2)$ and $7.31(1 \mathrm{H}, \mathrm{d}, J=15.86 \mathrm{~Hz}$, $\mathrm{C}-3)$ which were assigned as two trans protons. The doublet of doublet signals at $\delta_{\mathrm{H}} 3.45$ $\left(2 \mathrm{H}, \mathrm{dd}, J=7.07\right.$ and $\left.7.57 \mathrm{~Hz}, \mathrm{C}-1^{\prime}\right)$ and $2.75\left(2 \mathrm{H}, \mathrm{dd}, J=7.08\right.$ and $\left.7.57 \mathrm{~Hz}, \mathrm{C} 2^{\prime}\right)$ were determined as two methylene protons. Other four proton signals, at $\delta_{\mathrm{H}} 6.70(2 \mathrm{H}, \mathrm{m}, \mathrm{H}-6)$, $6.78(2 \mathrm{H}, \mathrm{m}, \mathrm{H}-5), 7.05\left(2 \mathrm{H}, \mathrm{dt} ; J=9.00\right.$ and $\left.2.00 \mathrm{~Hz}, \mathrm{H}-5^{\prime}\right)$, and $7.38(2 \mathrm{H}, \mathrm{dt} ; J=9.00$ and $\left.2.00 \mathrm{~Hz}, \mathrm{H}-8^{\prime}\right)$, were assigned as protons on two symmetric aromatic rings. The ${ }^{13} \mathrm{C}$ NMR showed thirteen carbon signals; however, they were indicated as seventeen carbons: one carbonyl carbon at $\delta_{\mathrm{C}} 169.25(\mathrm{C}-1)$; two methylene signals at $\delta_{\mathrm{C}} 35.82\left(\mathrm{C}-2^{\prime}\right)$ and $42.53\left(\mathrm{C}-1^{\prime}\right)$; two olefinic methine carbon signals at $\delta_{C} 118.49$ (C-2) and 141.76 (C-3); two quaternary carbon signals at $\delta_{\mathrm{C}} 127.77(\mathrm{C}-4)$ and $131.34\left(\mathrm{C}-3^{\prime}\right)$; two oxygenated aromatic carbons at $\delta_{\mathrm{C}} 156.92\left(\mathrm{C}-6^{\prime}\right)$ and $160.50(\mathrm{C}-7)$; eight tertiary aromatic carbons at $\delta_{\mathrm{C}} 130.3$ (C-5 and C-9), $116.72\left(\mathrm{C}-5^{\prime}\right.$ and $\left.\mathrm{C}-7^{\prime}\right), 116.28$ (C-6 and C-8), and $130.72\left(\mathrm{C}-4^{\prime}\right.$ and $\left.\mathrm{C}-8^{\prime}\right)$. The HRESIMS showed an $[\mathrm{M}+\mathrm{Na}]^{+}$ion at $m / z 306.1101$ (calcd. for $\left[\mathrm{C}_{17} \mathrm{H}_{17} \mathrm{NO}_{3}+\mathrm{Na}{ }^{+}\right)$, and correlated with a molecular formula of $\mathrm{C}_{17} \mathrm{H}_{17} \mathrm{NO}_{3}$. The structure of 5 was determined to be $N$-trans-coumaroyltyramine.

\subsection{Alpha-Glucosidase Inhibitory Assay}

To determined alpha-glucosidase inhibition, the percentage inhibition values at $2 \mathrm{mg} / \mathrm{mL}$ were used for the guided isolation, while the half maximal inhibitory concentration $\left(\mathrm{IC}_{50}\right)$ showed the inhibitory ability of compounds (Table 1). The coumarin derivative (1) and two tyramine-derived amides ( 4 and 5 ) exhibited stronger alpha-glucosidase inhibition than the positive control, acarbose.

Table 1. Inhibitory activity of isolated compounds from N. racemosa on alpha-glucosidase.

\begin{tabular}{|c|c|c|c|}
\hline Compounds & $\mathrm{IC}_{50}(\mu \mathrm{g} / \mathrm{mL})$ & Inhibition Type & $\mathrm{Ki}^{\mathrm{b}}$ or $\mathrm{Ki}^{\prime c}(\mu \mathrm{M})$ \\
\hline Scopoletin (1) & 110.97 & Mixed & - \\
\hline Syringic acid (2) & $>500$ & N.T. ${ }^{a}$ & - \\
\hline Methyl 3-methyl-2-butenoate (3) & $>500$ & N.T. ${ }^{a}$ & - \\
\hline$N$-trans-feruloyltyramine (4) & 29.87 & Uncompetitive & $51.81^{\mathrm{c}}$ \\
\hline$N$-trans-coumaroyltyramine (5) & 0.92 & Uncompetitive & $1.99^{\mathrm{C}}$ \\
\hline Acarbose (Positive control) & 272.72 & Competitive & $264.46^{\mathrm{b}}$ \\
\hline
\end{tabular}

a Not tested, ${ }^{\mathrm{b}}$ Inhibition constant when inhibitor bound with free enzyme, ${ }^{\mathrm{c}}$ Inhibition constant when inhibitor bound with enzyme-substrate complex. 


\subsection{Enzyme Kinetic Assay}

Compounds 1, 4, 5, and acarbose were evaluated their binding mode by the double reciprocal Lineweaver-Burk plot and the inhibition constants (Ki) were determined by secondary plot as shown in Figure 4. Lineweaver-Burk plots of compounds 4 and 5 indicated them to be typical of uncompetitive inhibition with $\mathrm{Ki}^{\prime}$ values were 51.81 and $1.99 \mu \mathrm{M}$, respectively, whereas the plot of $\mathbf{1}$ displayed mixed-type inhibition. The acarbose standard showed competitive inhibition with Ki values $264.46 \mu \mathrm{M}$. Therefore, these could be explained that compounds 4 and 5 were bound with alpha-glucosidase in separated site, compound 1 might both have interacted with the active site and separated site, while acarbose prohibited at the active site of enzyme. For a better understanding of compounds from $N$. racemosa, the molecular docking was performed.

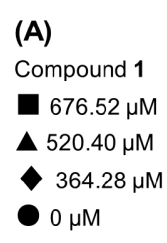

(B)

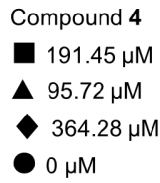

(C)

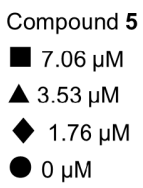

(D)

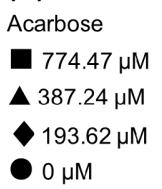

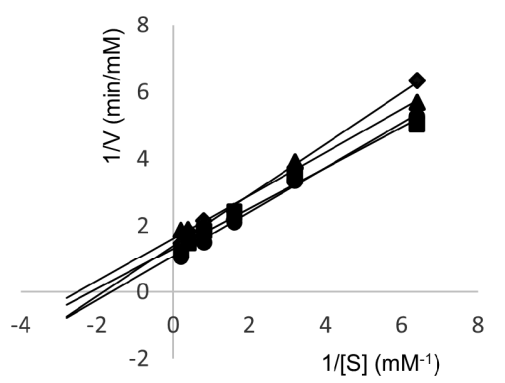
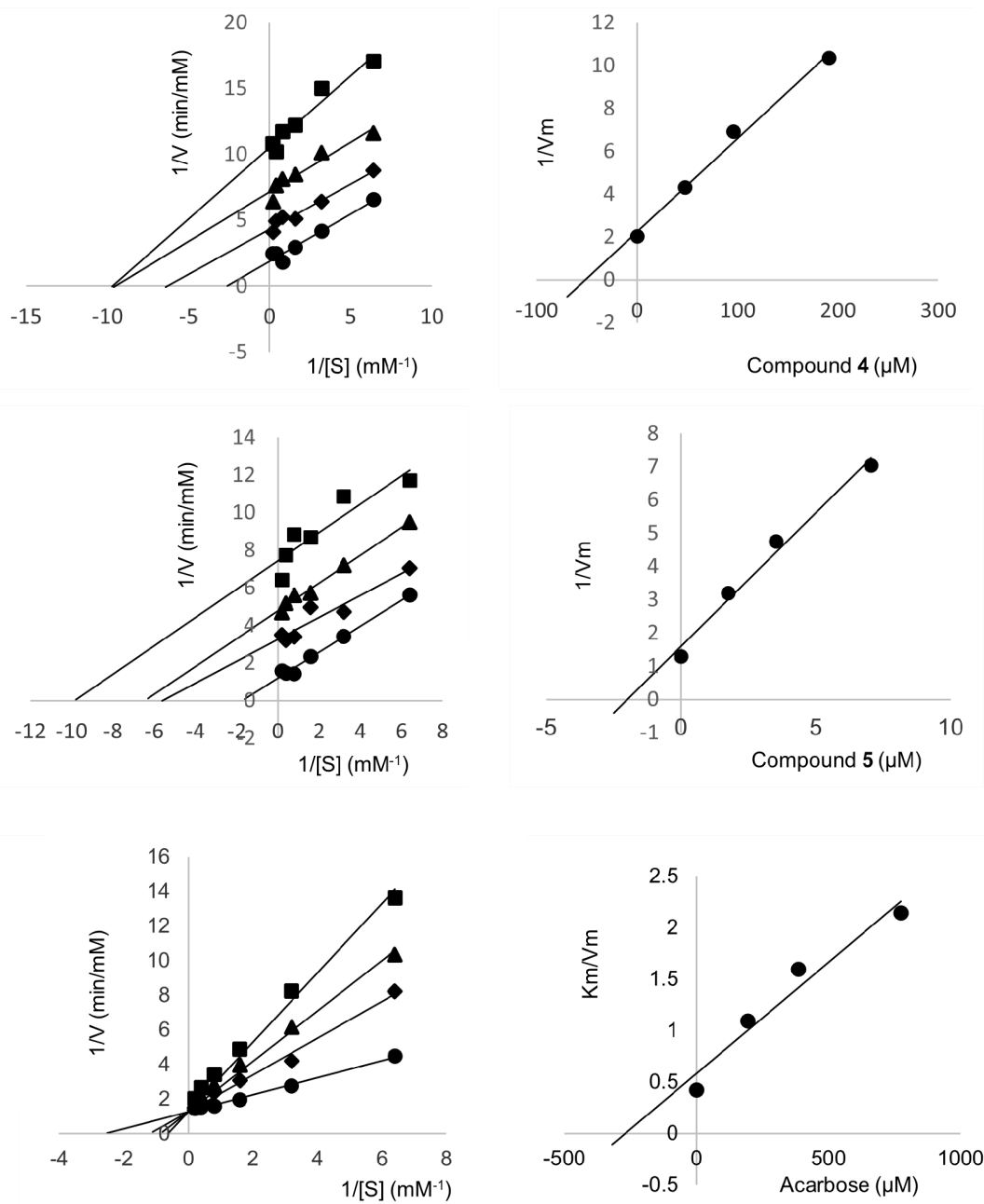

Figure 4. Lineweaver-Burk plots of compound 1, 4, 5, and acarbose, respectively (A-D). The secondary plots of each compound are on the right. 


\subsection{Molecular Docking}

Based on the structure-activity relationship, the compounds $1,2,4$, and 5 that have aromatic part in their structures were evaluated for the protein-ligand complexes. The results indicated that these compounds were bound with the same residues at the entrance area of the active site of alpha-glucosidase, as shown in Table 2 and Figure 5. These findings are in a good agreement with the previous studies, which suggested that the binding site of these compounds is around the active site of this enzyme [9-11]. It is well-known that the competitive inhibitor will prohibit the substrate to enter the active site of the enzyme. The docking result showed that compound $\mathbf{1}$ blocked the alpha-glucosidase entrance area as the line in Figure 5A,B. For an uncompetitive inhibitor, the mechanism of action is different from a competitive inhibitor. An uncompetitive inhibitor does not block the substrate from entering the active site, but rather, prevents the release of the product from the enzyme [11]. As can be seen in Figure 5A,C, the docking results suggest that the two tyramine-derived amides (compounds 4 and 5) were aligned at the exit part of the enzyme. This alignment would prohibit the release of the product from the alpha-glucosidase. These findings also agreed with previous studies of these two derivatives [12,13]. Moreover, this docking study showed that the binding of compound 2 either prevents the substrate entering the active site or the product leaving the enzyme, as shown in Table 2 and Figure 5A,B. It is consistent with the Costa and team study [9] which suggested that compound 2 might inhibit alpha-glucosidase either in a competitive or an uncompetitive manner.

Table 2. Molecular docking interaction of the alpha-glucosidase (AR) and selected compounds.

\begin{tabular}{|c|c|c|c|}
\hline Complex & Number(s) of Interaction & Interaction Sites & Distances (̊̊) \\
\hline $\mathrm{AR}-1$ & 1 & Glucose 601 & 1-Glucose $601(3.41 \AA)$ \\
\hline $\mathrm{AR}-2$ & 4 & $\begin{array}{c}\text { Tyr } 158 \\
\text { Glucose } 601\end{array}$ & $\begin{array}{c}\text { 2-Tyr } 158(2.05 \AA) \\
\text { 2-Glucose } 601(1.36 \AA) \\
\text { 2-Glucose } 601(3.14 \AA) \\
\text { 2-Glucose } 601(4.21 \AA)\end{array}$ \\
\hline $\mathrm{AR}-4$ & 4 & $\begin{array}{c}\text { Arg } 315 \\
\text { Asn } 415 \\
\text { Glucose } 601\end{array}$ & $\begin{array}{c}\text { 4-Arg } 315(4.60 \AA) \\
\text { 4-Asn } 415(4.18 \AA) \\
\text { 4-Glucose } 601(4.33 \AA) \\
\text { 4-Glucose } 601(3.21 \AA)\end{array}$ \\
\hline $\mathrm{AR}-5$ & 4 & $\begin{array}{c}\text { Arg } 315 \\
\text { Asn } 415 \\
\text { Glucose } 601\end{array}$ & $\begin{array}{c}\text { 5-Arg } 315(4.64 \AA) \\
\text { 5-Asn } 415(4.28 \AA) \\
\text { 5-Glucose } 601(4.14 \AA) \\
\text { 5-Glucose } 601(2.88 \AA)\end{array}$ \\
\hline
\end{tabular}

Two tyramine-derived amides (compounds 4 and 5) are the promising compounds in the future of the anti-diabetes treatment, since they could strongly inhibit the activity from the alpha-glucosidase and their mode of inhibition (an uncompetitive manner) provided a superior for drug development in the animal model compared with the other modes of inhibition. Even compounds $\mathbf{4}$ and $\mathbf{5}$ are highly attractive, but only few studies have examined their structure-activity relationship. Song and team [11] suggested that the hydroxyl group at the ring A (coumaroyl moiety, Figure $5 \mathrm{D}, \mathrm{E}$ ) and $\alpha-\beta$ unsaturated carbonyl group (Figure 5E) played an important role in the interaction between these two derivatives and alpha-glucosidase. In addition, the substitution of the methoxyl group at the position of C-6 of the ring A caused a significant decrease in the inhibitory activity against the alpha-glucosidase [12]. Therefore, this effect has been used as a reason to explain why compound 4 exhibited less potency than compound 5. However, it is still unclear how the substitution of this methoxyl group at the position of C-6 impacts the conformation from these compounds at the molecular level and contribute to a better inhibitory activity. Therefore, we evaluated the best poses of compounds 4 and 5 from the molecular docking (as can been seen in Figure 5D,E) and rescoring the obtained binding energy from Autodock 
Vina using Autodock 4 to obtain more molecular interaction parameters (Table 3). The results indicated that the substitution at C- 6 did not only rotate ring A approximately 60 degrees (Figure 5D), but also turned the $\alpha-\beta$ unsaturated carbonyl group away around 160 degree (Figure 5E). Even this substitution created a great impact in the geometrical structure of these compounds, but these seemed to have less impact in terms of the distance between atoms of these compounds and the residues from the alpha-glucosidase (Table 2). Furthermore, it showed a contradiction in the predicted binding energy showing that compound 4 had a more potent inhibitory activity (lower binding energy) than compound 5 (Table 3). The rescored prediction showed a similar result. However, it pointed out that methoxyl substitution at C-6 of the ring A on compound 4 contributed to higher desolvation and torsion energies (less favorable for enzyme inhibition) than compound 5, as presented in Table 3. Therefore, these two parameters might be used to explain why compound 5 showed a stronger activity than compound 4 . Although the geometric and energetic changes between compound $\mathbf{4}$ and $\mathbf{5}$ from our docking models seem to be inconclusive based on the ligand-enzyme interaction, these alterations have enough impact to cause the difference as high as 30 -folds in the anti-glucosidase activity in the in vitro study as mentioned as above.

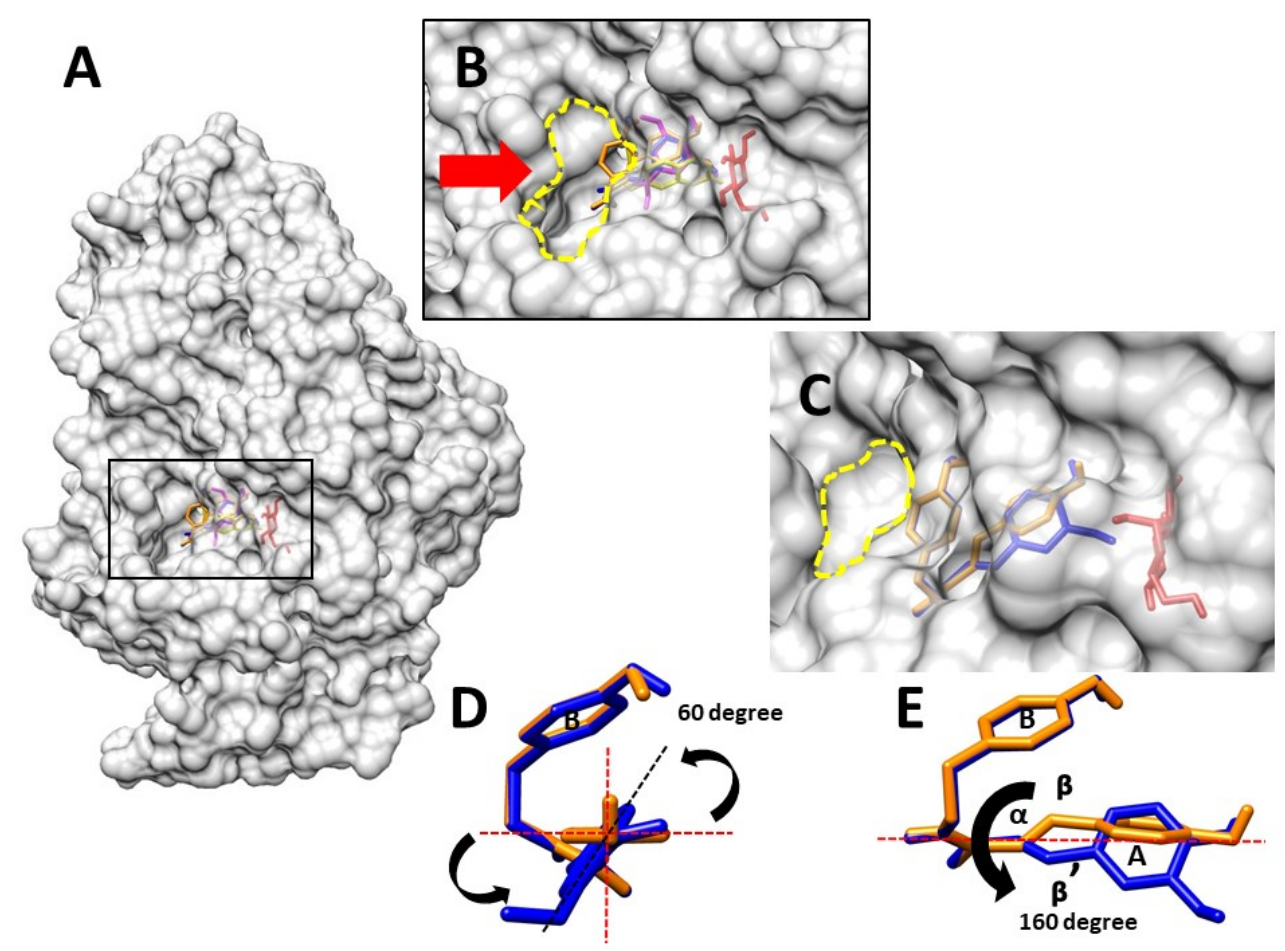

Figure 5. The molecular interaction between the alpha-glucosidase, presented in grey color and glucose as in red color, $\mathbf{1}$ as in yellow color, $\mathbf{2}$ as in pink color, $\mathbf{4}$ in blue color and $\mathbf{5}$ as in orange color, respectively. (A) The molecular interaction between the alpha-glucosidase and the mentioned. (B) The expanded picture at the active site of the alpha-glucosidase. The dashed circle in yellow color indicated the entrance gate to the active site, while the red arrow was used to emphasis this gate. (C) The comparison between the docked conformations of $\mathbf{4}$ in blue color and $\mathbf{5}$ as in orange color at the entrance gate of the active site. $(\mathrm{D}, \mathrm{E})$ The alteration of the docked conformation between 4 as in blue color and 5 as in orange color. The red dashed lines indicated the $\mathrm{X}$ and Y-axis, while the black arrows indicated the changing of the position in the chemical structure. 
Table 3. Rescoring binding energy of the interested compounds (1 to 5) from Autodock 4.2.6 compared to Autodock Vina.

\begin{tabular}{|c|c|c|c|c|c|c|c|c|c|}
\hline \multicolumn{9}{|c|}{ Autodock 4.2.6 } & \multirow{2}{*}{$\begin{array}{c}\begin{array}{c}\text { Autodock } \\
\text { Vina }\end{array} \\
\text { Affinity } \\
\text { (Kcal/mol) }\end{array}$} \\
\hline Compound & $\begin{array}{l}\text { vdW+ } \\
\text { Hbond } \\
\text { (I) }\end{array}$ & $\begin{array}{c}\text { Elec. } \\
\text { Energy } \\
\text { (II) }\end{array}$ & $\begin{array}{l}\text { Desol. } \\
\text { energy } \\
\text { (III) }\end{array}$ & $\begin{array}{c}\text { Total } \\
\text { Intermol. } \\
\text { Interact. } \\
\text { Energy } \\
\text { (IV; } \\
\text { I+II+III) }\end{array}$ & $\begin{array}{c}\text { Total } \\
\text { Internal } \\
\text { Energy } \\
\text { (V) }\end{array}$ & $\begin{array}{l}\text { Tors. Free } \\
\text { Energy } \\
\text { (VI) }\end{array}$ & $\begin{array}{l}\text { Unbound's } \\
\text { Energy } \\
\text { (VII) }\end{array}$ & $\begin{array}{c}\text { Binding } \\
\text { Energy } \\
\text { (Kcal/mol) } \\
\text { (VIII; } \\
\text { IV+V+ } \\
\text { VI+VII) }\end{array}$ & \\
\hline 1 & -6.34 & 0.01 & 1.80 & -4.53 & -0.69 & 0.6 & 0 & -4.62 & -6.3 \\
\hline 2 & -6.67 & 1.70 & 3.00 & -1.98 & -0.58 & 1.49 & 0 & -1.07 & -5.7 \\
\hline 4 & -9.27 & 0.30 & 2.60 & -6.36 & -1.45 & 2.39 & 0 & -5.42 & -7.5 \\
\hline 5 & -8.22 & 0.29 & 2.05 & -5.88 & -1.36 & 2.09 & 0 & -5.15 & -7.0 \\
\hline
\end{tabular}

$\mathrm{vdW}+$ Hbonding $=$ Van der Waals + Hydrogen bonding, Elec. energy = Electrostatic energy, Desol. energy = Desolvation energy, Total Intermol. Interact. energy = Total Intermolecule Interaction energy, Tors. free energy = Torsion free energy. Highlighted color $=$ higher energy of compound 5 than compound 4.

\section{Discussion}

Alpha-glucosidase is one target enzyme for reduce glucose level in the management of type 2 diabetes mellitus. The $N$. racemosa stem crude extract showed the strong effect towards the enzyme as $96.09 \%$ inhibition at $2 \mathrm{mg} / \mathrm{mL}$. For the extraction, step polarity solvents used were increased from $n$-hexane, EtOAc, EtOH, and water, respectively. The bioactivity-guided fractionation indicated that the ethanol extract had the highest activity among these extracts with an $\mathrm{IC}_{50}$ of $39.65 \mu \mathrm{g} / \mathrm{mL}$. The chromatographic techniques conducted the isolation of five compounds (1-5). Their chemical structures were determined by $1 \mathrm{D}$ and $2 \mathrm{D}$ NMR analysis. The first time, compound 1 was confusing of its substitution at C-7 and C-8. The NOESY experiment showed the correlation signal between proton of C-6 and methoxyl proton of C-7. Therefore, compound $\mathbf{1}$ was indicated as scopoletin that is different from iso-scopoletin. Islam and team [14] suggested that the substitution at the 7th and 8th position on the coumarin skeleton results in the alpha-glucosidase inhibitory activity. Compound 1 which has methoxylation and hydroxylation at the 7th and 8th position, respectively, exhibited the alpha-glucosidase more than the compound which does not have these substitutions [14]. This indicated that the substituted group of compound $\mathbf{1}$ may result to protein interaction. Moreover, another study reported that compound $\mathbf{1}$ also has the potent inhibitory activity towards another anti-diabetic enzyme, alpha-amylase [15]. Compound 2 was a phenolic compound that was found in various fruits and vegetables and was claimed in therapeutic application for diabetic. The crucial part of $\mathbf{2}$ was the methoxyl substitution at positions 3 and 5 of the phenol ring [16]. Compound 3 was an $\alpha, \beta$-unsaturated ester molecule that has not been reported in regards to diabetic activity. Compounds 4 and 5 were phenylethyl cinnamide derivatives which have a difference of methoxyl substitution. The structure-activity relation study showed that the substitutions of ring A influence the alpha-glucosidase inhibitory activity [11].

The alpha-glucosidase inhibitory activity of isolated compounds, 1,4 , and 5 was evaluated as the dose-dependent manner which is shown in Table 1 . The coumarin derivative (1) and tyramine-derived amides (4 and $\mathbf{5}$ ) was isolated from many plants [12-15,17-19]. Our study showed the alpha-glucosidase inhibitory activity of $\mathbf{1}$ as an $\mathrm{IC}_{50}$ of $110.97 \mu \mathrm{g} / \mathrm{mL}$ $(577.50 \mu \mathrm{M})$, while other studies presented various $\mathrm{IC}_{50}$ such as $0.057 \mu \mathrm{M}$ [15], $85.12 \mu \mathrm{M}$ [18], and $159.16 \mu \mathrm{M}$ [14]. Compounds 4 and 5 were often isolated from the same plant [12,13], including in our study. In Table 1 , the $\mathrm{IC}_{50}$ of 4 is $29.87 \mu \mathrm{g} / \mathrm{mL}(95.34 \mu \mathrm{M})$ and the $\mathrm{IC}_{50}$ of 5 is $0.92 \mu \mathrm{g} / \mathrm{mL}(3.25 \mu \mathrm{M})$. The previous reports showed the $\mathrm{IC}_{50}$ of 4 as $3.58 \mu \mathrm{M}$ [13] and $500.60 \mu \mathrm{M}$ [12], while the $\mathrm{IC}_{50}$ of 5 was presented as $0.40 \mu \mathrm{M}$ [19], $0.42 \mu \mathrm{M}$ [17], $0.58 \mu \mathrm{M}$ [13], and $5.3 \mu \mathrm{M}$ [12]. The different inhibitory values of the compounds may result from different conditions tested. Besides this, the $\mathrm{IC}_{50}$ of compounds 2 and 3 was more than $500 \mu \mathrm{g} / \mathrm{mL}$. Therefore, our kinetic study focused on in vitro active isolated compounds $(\mathbf{1}, \mathbf{4}$ and $\mathbf{5})$. The 
kinetic prediction is that compound $\mathbf{1}$ was a mixed type inhibitor while tyramine-derived amides (compounds 4 and 5) inhibited the alpha-glucosidase in an uncompetitive manner. However, the literature reported that compound $\mathbf{1}$ was a competitive inhibitor towards alpha-glucosidase [20]. In the competitive manner, the inhibitor binds to the free enzyme active site, while the mixed-type manner requires two inhibitors to bind to the enzyme at more than one site [17]. For compounds 4 and 5, our study agreed with the previous report that showed uncompetitive interaction [11,13]. However, some authors [12] suggested that the mechanisms of compounds 4 and 5 were those of non-competitive inhibitors. The uncompetitive manner is the inhibitor binding to the enzyme-substrate (ES) complex, while the non-competitive manner is the situation that inhibitors bind to both the free enzyme and ES complex with an equivalent affinity [17]. The different study condition may result in the different binding detection, especially in separated sites.

To understand the comprehensive interaction between isolated compounds and alphaglucosidase, the compounds that have aromatic ring (compounds 1, 2, 4 and 5) were evaluated for the binding site inhibition in molecular level. The results from the molecular docking experiment in this study suggested that these selected bioactive compounds from $N$. racemosa could bind at the same site, the entrance area of the active site, of the alphaglucosidase. These findings were in a good agreement with the previous independent studies of each compound [9-11] and provided comprehensive evidence of the molecular interaction among these compounds and the alpha-glucosidase. Even their modes of inhibition were reported differently, but the results here, in this study, indicated that they could bind exactly at the same binding site. There is a hypothesis that states as a synergistic effect could occur when combining two inhibitors, which had a different mode of inhibition together [21]. Therefore, the question is raised that if it will be the case here with these bioactive compounds from $N$. racemosa. To address this question, further investigations are required. To the best of our knowledge, this was the first study that reported the difference between the molecular conformation from these two-promising alpha-glucosidase inhibitors, namely $N$-trans-feruloyltyramine (4) and $N$-trans-coumaroyltyramine (5). Based on the existing knowledge, it was possible to believe that this molecular alteration is caused by the impact of the C-6 substitution of the methoxyl group at the coumaroyl moiety. Therefore, this is the new evidence that showed the effect of this impact at the molecular level. However, it is necessary to perform further experiments for an absolute conclusion.

\section{Experimental Section}

\subsection{General}

Classical column chromatography was used for phytochemical investigation. Silica gel (Vertical, Thailand) and Sephadex ${ }^{\circledR}$ LH-20 (Bio-Sciences, Uppsala, Sweden) were performed as material of normal phase and molecular sieves chromatography, respectively. Thin-layer chromatography (TLC) plate pre-coated with silica gel $60 \mathrm{~F}_{254}$ (Merck, Darmstadt, Germany) was used for pretest of purified investigation. TLC spots were detected under daylight, UV light (254 nm and $366 \mathrm{~nm}$ ) and/or sprayed with $20 \% \mathrm{H}_{2} \mathrm{SO}_{4}$. Chromatographic solvents were distilled in our laboratory before used. One-dimensional and two-dimensional NMR spectra were obtained by using a Fourier Transform NMR Spectrometer $500 \mathrm{MHz}$ (Varian, Frankfurt, Germany), in dimethyl sulfoxide (DMSO- $\left.d_{6}\right)$ and chloroform $\left(\mathrm{CDCl}_{3}\right)$. UV/Vis spectra were measured on UV-Spectrophotometer Genesys 6 (Thermo, Frankfurt, Germany). IR spectra were determined by Spectrum One FT-IR Spectrometer (PerkinElmer, Buckinghamshire, UK). High resolution electron spray ionization mass spectrometry (HRESIMS) was analyzed by using liquid chromatograph-quadrupole time of fight mass spectrometer (Agilent, CA, USA). The isolated compounds (scopoletin (1), syringic acid (2), methyl 3-methyl-2-butenoate (3), N-trans-feruloyltyramine (4) and N-trans-coumaroyltyramine (5)) have purity more than $95 \%$. 


\subsection{Plant Material}

The stem of N. racemosa was collected from Songkhla province, Thailand, 2014. The herbal material was identified by Assoc. Prof. Dr. Orathai Neamsuvan, Faculty of Traditional Thai Medicine, Prince of Songkla University and the voucher specimen (SKP 05414 18 01) has been deposited at Department of Pharmacognosy and Pharmaceutical Botany, Faculty of Pharmaceutical Sciences, Prince of Songkla University, Thailand.

\subsection{Extraction and Isolation}

Fresh plant materials $(10 \mathrm{~kg})$ were washed and then dried in the oven at temperature $50{ }^{\circ} \mathrm{C}$ until dryness. The dried materials $(3.1 \mathrm{~kg})$ were macerated with $n$-hexane 3 days in triplicate. The marc and filtrated were separated. The marc was macerated again by the same procedure with ethyl acetate, ethanol and boiled with filtrated water, respectively. Each filtrated solvent was evaporated by reduced pressure at $50{ }^{\circ} \mathrm{C}$. All extracts were kept at $4{ }^{\circ} \mathrm{C}$ until used. Due to the bioassay guided isolation, the ethanol crude extract ( $25.01 \mathrm{~g}$ ) was subjected to silica flash column using gradient of $n$-hexane to EtOH to achieve 16 fractions $\left(\mathrm{A}_{1}-\mathrm{A}_{16}\right)$.

Fractions $A_{7}$ and $A_{8}$ were combined and subjected to silica column by using the gradient of mobile phase as $\mathrm{CHCl}_{3}$ to $\mathrm{CHCl}_{3}-\mathrm{MeOH}(1: 1)$ to give 12 fractions $\left(\mathrm{B}_{1}-\mathrm{B}_{12}\right)$. Fraction $\mathrm{B}_{4}$ and $\mathrm{B}_{5}$ were combined and separated on size exclusion method with Sephadex ${ }^{\circledR}$ LH-20 column to give 6 sub-fractions $\left(C_{1}-C_{6}\right) . C_{4}$ and $C_{5}$ were combined and further chromatographed on silica column and using the gradient of mobile phase with increasing the polarity by mixing $\mathrm{CHCl}_{3}$ to EtOAc and EtOAc-MeOH (9:1) to afford compound 1 (3.9 mg). Fraction $\mathrm{B}_{8}$ and $\mathrm{B}_{9}$ were combined and subjected to silica column and using the gradient of mobile phase as $\mathrm{CH}_{2} \mathrm{Cl}_{2}$ to EtOAc and EtOAc-MeOH (9:1) to give 15 subfractions $\left(\mathrm{D}_{1}-\mathrm{D}_{15}\right)$. Sub-fractions $\mathrm{D}_{10}$ and $\mathrm{D}_{15}$ were pooled and washed by EtOAc to yield compound 2 (1.9 $\mathrm{mg})$.

Fraction $\mathrm{A}_{13}$ and $\mathrm{A}_{14}$ were combined and separated by using silica column and gradient mobile phase as EtOAc to EtOAc-MeOH (1:1) to give 16 sub-fractions $\left(\mathrm{E}_{1}-\mathrm{E}_{16}\right)$. Sub-fractions $\mathrm{E}_{6}$ and $\mathrm{E}_{7}$ were combined and subjected to silica column with using gradient mobile phase of $\mathrm{CHCl}_{3}$ to $\mathrm{CHCl}_{3}-\mathrm{MeOH}$ (9:1) to achieve compound 3 (1.4 mg).

Fraction $\mathrm{A}_{10}$ was chromatographed on silica column and using the gradient mobile phase as $n$-hexane-EtOAc (1:1) to EtOAc-MeOH (9:1) to give 23 fractions $\left(\mathrm{F}_{1}-\mathrm{F}_{23}\right)$. Fractions $\mathrm{F}_{8}-\mathrm{F}_{11}$ were pooled and partitioned with $n$-hexane, $\mathrm{CHCl}_{3}$, and $\mathrm{MeOH}$ to yield 3 solvent extracts. The methanolic extract from the partition of $\mathrm{F}_{8}-\mathrm{F}_{11}$ was continuously subjected to silica column and using gradient mobile phase of $\mathrm{CHCl}_{3}$ to $\mathrm{CHCl}_{3}-\mathrm{MeOH}$ (9:1) to isolate compound 4 (1.8 $\mathrm{mg})$ and compound 5 (9.9 $\mathrm{mg})$.

\subsection{Spectroscopic Data}

\subsubsection{Scopoletin (1)}

Yellow pale needles; $\mathrm{C}_{10} \mathrm{H}_{8} \mathrm{O}_{4} ; \mathrm{UV}\left(\mathrm{CHCl}_{3}\right) \lambda_{\max } 341 \mathrm{~nm} ; \mathrm{IR} v_{\max } \mathrm{cm}^{-1}$ : 3460, 1651, 1218, 772, 669; ${ }^{1} \mathrm{H}$ NMR $\left(\mathrm{CDCl}_{3}\right) \delta: 7.58(1 \mathrm{H}, \mathrm{d}, J=9.5 \mathrm{~Hz}, \mathrm{H}-4), 6.90(1 \mathrm{H}, \mathrm{s}, \mathrm{H}-9), 6.63(1 \mathrm{H}$, s, H-6), $6.25(1 \mathrm{H}, \mathrm{d}, J=9.5 \mathrm{~Hz}, \mathrm{H}-3), 6.17(1 \mathrm{H}, \mathrm{s}, 8-\mathrm{OH}), 3.94\left(3 \mathrm{H}, \mathrm{s}, 7-\mathrm{OCH}_{3}\right) ;{ }^{13} \mathrm{C} \mathrm{NMR}$ $\left(\mathrm{CDCl}_{3}\right)$ ): 161.43 (C-2), 150.23 (C-10), 149.64 (C-8), 143.96 (C-7), 143.29 (C-4), 113.42 (C-3), 111.48 (C-5), 107.44 (C-6), $103.18(\mathrm{C}-9), 56.39\left(\mathrm{CH}_{3}\right)$.

\subsubsection{Syringic Acid (2)}

Orange amorphous solid; $\mathrm{C}_{9} \mathrm{H}_{10} \mathrm{O}_{5} ; \mathrm{UV}(\mathrm{MeOH}) \lambda_{\max } 289 \mathrm{~nm}$; IR $v_{\max } \mathrm{cm}^{-1}$ : 3434, 2066, 1634, 1523, 1468, 1426, 1335, 1281, 1217, 1126, 1015; ${ }^{1} \mathrm{H}$ NMR (DMSO-d 6 ) $\delta: ~ 7.19$ (2H, s, $\mathrm{H}-2, \mathrm{H}-6), 9.07\left(1 \mathrm{H}\right.$, brs, 1-COOH), $3.78\left(6 \mathrm{H}, \mathrm{s}, 3-\mathrm{OCH}_{3}, 5-\mathrm{OCH}_{3}\right)$. HR-ESIMS (negative-ion mode) $m / z 197.0456[\mathrm{M}-\mathrm{H}]^{-}\left(\right.$calcd. for $\left.\left[\mathrm{C}_{9} \mathrm{H}_{10} \mathrm{NO}_{5}-\mathrm{H}\right]^{-}\right)$.

\subsubsection{Methyl 3-Methyl-2-butenoate (3)}

Brown amorphous solid; $\mathrm{C}_{6} \mathrm{H}_{10} \mathrm{O}_{2} ; \mathrm{UV}\left(\mathrm{CHCl}_{3}\right) \lambda_{\max } 290 \mathrm{~nm} ; \mathrm{IR} v_{\max } \mathrm{cm}^{-1}: 2922$, $1698,1645,1595,1457,1322,1260,1220,1110,874,800 ;{ }^{1} \mathrm{H} \mathrm{NMR}\left(\mathrm{CDCl}_{3}\right) \delta: 5.80(1 \mathrm{H}, \mathrm{s}, \mathrm{H}-2)$, 


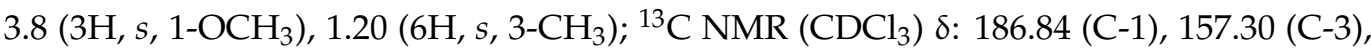
107.42 (C-2), $\left.56.4\left(\mathrm{OCH}_{3}-1\right), 29.69 \mathrm{C}-4\right), 29.35\left(\mathrm{CH}_{3}-3\right)$.

\subsubsection{N-trans-Feruloyltyramine (4)}

White amorphous solid; UV (MeOH) $\lambda_{\max } 318 \mathrm{~nm}$; IR $v_{\max } \mathrm{cm}^{-1}: 3434,1652,1542$, $1515,1457,1269,1125,1032,978,819,670 ;{ }^{1} \mathrm{H}\left(\right.$ DMSO- $\left._{6}\right) \delta: 7.42(1 \mathrm{H}, \mathrm{d}, J=15.62 \mathrm{~Hz}, \mathrm{H}-3)$, $7.11(1 \mathrm{H}, \mathrm{d}, J=1.95 \mathrm{~Hz}, \mathrm{H}-5), 7.05\left(2 \mathrm{H}, \mathrm{dd}, J=9.27,2.40 \mathrm{~Hz}, \mathrm{H}-4^{\prime}, \mathrm{H}-8^{\prime}\right), 7.01(1 \mathrm{H}, \mathrm{dd}$, $J=8.29,1.95 \mathrm{~Hz}, \mathrm{H}-9), 6.78(1 \mathrm{H}, \mathrm{d}, J=8.06 \mathrm{~Hz}, \mathrm{H}-8), 6.72\left(2 \mathrm{H}, \mathrm{dd}, J=9.27,2.40 \mathrm{~Hz}, \mathrm{H}-5^{\prime}\right.$, $\left.\mathrm{H}-7^{\prime}\right), 6.39(1 \mathrm{H}, \mathrm{d}, J=15.62 \mathrm{~Hz}, \mathrm{H}-2), 3.87\left(3 \mathrm{H}, \mathrm{s}, \mathrm{OCH}_{3}-6\right), 3.45(1 \mathrm{H}, \mathrm{dd}, J=7.08,7.56 \mathrm{~Hz}$, C-1' $\left.{ }^{\prime}\right), 2.75\left(1 \mathrm{H}, \mathrm{dd}, J=7.08,7.56 \mathrm{~Hz}, \mathrm{C}-2^{\prime}\right) ;{ }^{13} \mathrm{C}$ NMR (DMSO-d 6 ) $\delta: 169.19$ (C-1), 156.94 (C-6'), 149.88 (C-7), 149.32 (C-6), 142.01 (C-3), 131.33 (C-3'), 130.72 (C-4', C-8'), 128.31 (C-4), 123.22 (C-9), 118.79 (C-2), 116.42 (C-8), $116.28\left(\mathrm{C}-5^{\prime}, \mathrm{C}-7^{\prime}\right), 111.63$ (C-5), $56.42\left(\mathrm{OCH}_{3}-6\right)$, $42.53\left(\mathrm{C}-1^{\prime}\right), 35.81\left(\mathrm{C}-2^{\prime}\right)$; HR-ESIMS (positive-ion mode) $\mathrm{m} / \mathrm{z} 336.1206[\mathrm{M}+\mathrm{Na}]^{+}$(calcd. for $\left.\left[\mathrm{C}_{18} \mathrm{H}_{19} \mathrm{NO}_{4}+\mathrm{Na}\right]^{+}\right)$.

\subsubsection{N-trans-Coumaroyltyramine (5)}

White amorphous solid; UV (MeOH) $\lambda_{\max } 295 \mathrm{~nm}$; IR $v_{\max } \mathrm{cm}^{-1}: 3434,1637,1541$, 1456, 1245, 1174, 1105, 980, 830; ${ }^{1} \mathrm{H}\left(\mathrm{DMSO}_{6}\right) \delta: 7.44(1 \mathrm{H}, \mathrm{d}, J=15.86 \mathrm{~Hz}$, ah-3), $7.38(2 \mathrm{H}$, $\left.\mathrm{dt}, J=9.00,2.00 \mathrm{~Hz}, \mathrm{H}-4^{\prime}, \mathrm{H}-8^{\prime}\right), 7.05\left(2 \mathrm{H}, \mathrm{dt}, J=9.00,2.00 \mathrm{~Hz}, \mathrm{H}-5^{\prime}, \mathrm{H}-7^{\prime}\right), 6.78(2 \mathrm{H}, \mathrm{m}, \mathrm{H}-5$, H-9), $6.70(2 \mathrm{H}, \mathrm{m}, \mathrm{H}-6, \mathrm{H}-8), 6.38(1 \mathrm{H}, \mathrm{d}, J=15.86 \mathrm{~Hz}, \mathrm{H}-2), 3.45(2 \mathrm{H}, \mathrm{dd}, J=7.07,7.57 \mathrm{~Hz}$, $\left.\mathrm{H}-1^{\prime}\right), 2.75\left(2 \mathrm{H}, \mathrm{dd}, J=7.57,7.08 \mathrm{~Hz}, \mathrm{H2}{ }^{\prime}\right) ;{ }^{13} \mathrm{C}$ NMR (DMSO- $\left.d_{6}\right) \delta: 169.25$ (C-1), 160.50 (C-7), 156.92 (C-6'), 141.76 (C-3), $131.34\left(\mathrm{C}-3^{\prime}\right), 130.72\left(\mathrm{C}-4^{\prime}, \mathrm{C}-8^{\prime}\right), 130.53$ (C-5, C-9), 127.77 (C-4), 118.49 (C-2), 116.72 (C-5', C-7'), 116.28 (C-6, C-8), 42.53 (C-1'), 35.82 (C-2'); HR-ESIMS (positive-ion mode) $m / z 306.1101[\mathrm{M}+\mathrm{Na}]^{+}\left(\right.$calcd. for $\left[\mathrm{C}_{17} \mathrm{H}_{17} \mathrm{NO}_{3}+\mathrm{Na}\right]^{+}$).

\subsection{Enzymatic Assay}

The alpha-glucosidase inhibitory assay was slightly modified from Dej-adisai and Pitakbut, 2015 [22]. This assay was determined by a colorimetric method which observed the yellow product, $p$-nitrophenol ( $p \mathrm{NP})$, and detected by visible light at $405 \mathrm{~nm}$ with a SPECTROstar Nano spectrophotrometer (BMG Labtech, Ortenberg, Germany). The UV absorbance of the final product, $p \mathrm{NP}$, was converted to velocity $(\mathrm{V})$ by the following equation:

$$
\text { Velocity }=\Delta \text { Absorbance at } 405 \mathrm{~nm} / \Delta \text { Time }
$$

while the velocity was calculated percentages of inhibition as in the following equation:

$$
\% \text { Inhibition }=\left[\left(\mathrm{V}_{\text {control }}-\mathrm{V}_{\text {sample }}\right) / \mathrm{V}_{\text {control }}\right] \times 100
$$

The $\mathrm{IC}_{50}$ value that performed the inhibition ability of samples was received from the calibration curve plotted between percentages of inhibition and five concentrations of samples.

\subsection{Enzyme Kinetic Study}

The double reciprocal Lineweaver-Burk plot was used to determine the mode of inhibition, while the secondary plots conducted the inhibition constants. The inhibition constant was showed as Ki values when the inhibitor binds with free enzyme for competitive inhibition, but it was showed as $\mathrm{Ki}^{\prime}$ values when the inhibitor binds with the enzyme-substrate complex for uncompetitive inhibition. Briefly, the enzyme inhibition procedure was performed as mention above. The 6 concentrations of $p$ NPG $(5-0.1 \mathrm{mM})$, the fixed enzyme concentration ( $1 \mathrm{unit} / \mathrm{mL})$, and the 3 concentrations of each effective sample were evaluated for the manner of inhibition.

\subsection{Molecular Docking}

Autodock Vina version 1.1.2 from the Scripps Research Institute, San Diego, California, USA was used to investigate the molecular interaction in this study [9]. The target protein, 
the alpha-glucosidase (PDB ID: 3a4a), was downloaded from RCSB Protein Data Bank (https://www.rcsb.org/, accessed on 1 May 2021), while the compounds of interest were downloaded from Pubchem (https://pubchem.ncbi.nlm.nih.gov/, accessed on 1 May 2021). Before performing the experiment, both the alpha-glucosidase and the compounds of interest needed to be prepared properly. Firstly, Autodock Tool version 1.5.6 from the same institute as Autodock Vina was used to prepare the alpha-glucosidase and to identify the active site of this enzyme by using the native ligand, the glucose molecule, as a guideline [23]. The center of this active site was determined and presented as the three-dimensional grid, which $X=21.1, Y=-7.4$ and $Z=24.2$, respectively. This grid had a size of $17 \AA \times 17 \AA \times 17 \AA$. Secondly, Avogadro Version 1.2.0 was used to perform the two steps energy minimization for all the compounds in this study. The first step performed a geometric optimization and the following by a general amber force field, GAFF [24]. To perform this experiment, all docking parameters must be defined and almost all these parameters were set as a default. Only the exhaustiveness value was adjusted to 24. Importantly, this protocol was validated by re-docking the native ligand of the glucose molecule into the identified active site of this $\alpha$-glucosidase under the setup condition, as described earlier, before applying this protocol in this study. As expected, the re-docking result passed the acceptance criterion, since the RMSD was less than $1 \AA$ [25]. The trial result would not be presented here, but rather, in the supplementary file. Therefore, this protocol is reliable and ready for the experiment. For post-docking analysis, Chimera version 1.11.2 together with viewdock package [26] was used to visualize and evaluate the outcomes from this experiment. Finally, we rescored the binding energy of the best docking pose using Autodock 4.2.6, following previous reports [25,27].

\section{Conclusions}

This study would be the first report on the phytochemical investigation of Neuropeltis racemosa which is used as the component of many traditional Thai recipes. The bioassayguided fractionation on alpha-glucosidase inhibition revealed that the best active extract is the ethanolic extract. The extracts were separated by using classical column chromatographic techniques and five compounds were obtained. The spectroscopic techniques including UV-Vis, FTIR, HRMS, and NMR $\left({ }^{1} \mathrm{H}-\mathrm{NMR},{ }^{13} \mathrm{C}-\mathrm{NMR}, \mathrm{HMQC}, \mathrm{HMBC}\right.$, NOESY) analyses revealed the chemical structure of the isolated compounds. Then, the compounds were estimated for their bioactive potential of alpha-glucosidase inhibition. Moreover, three compounds (compound 1, 4, and 5) which have the better activity than the standard acarbose were chosen for the mechanism of action analysis. Some of them exhibited the significant alpha-glucosidase inhibition with different mechanism of action. Besides this, an in silico study exposed the alpha-glucosidase inhibition of selected compounds (compound 1, 2, 4, and 5) at the molecular level. The parameters of molecular docking such as binding energy, desolvation, and torsion energy were used for the explanation of the molecular interaction. Based on the results, these findings justify the value of $N$. racemosa as a component of traditional medicine and resource of lead antidiabetic compounds for further study.

Author Contributions: Conceptualization and supervision, S.D.-a.; methodology, S.D.-a., O.S. and T.P.; investigation, O.S. and T.P.; writing — original draft preparation, O.S., T.P. and S.D.-a.; writingreview and editing, S.D.-a.; co-supervision, C.W.; funding acquisition, S.D.-a. All authors have read and agreed to the published version of the manuscript.

Funding: This study was supported by Discipline of Excellence in Pharmacy through Faculty of Pharmaceutical Sciences funded by Research and Development Office, Prince of Songkla University.

Institutional Review Board Statement: Not applicable.

Informed Consent Statement: Not applicable.

Data Availability Statement: Data sharing is not applicable. 


\begin{abstract}
Acknowledgments: The author would like to thank Orathai Neamsuvan, Faculty of Traditional Thai Medicine, Prince of Songkla University for herbal identification. We would like to thank the Department of Pharmacognosy and Pharmaceutical Botany and the Pharmaceutical Laboratory Center, Faculty of Pharmaceutical Sciences, Prince of Songkla University for the laboratory space and equipment.
\end{abstract}

Conflicts of Interest: The authors declare no conflict of interest.

Sample Availability: Samples of the compounds are available from the authors.

\title{
References
}

1. IDF Diabetes Atlas Tenth Edition 2021. International Diabetes Federation (IDF). Available online: https://diabetesatlas.org/ idfawp/resource-files/2021/07/IDF_Atlas_10th_Edition_2021.pdf (accessed on 25 December 2021).

2. American Diabetes Association (ADA). Pharmacologic Approaches to Glycemic Treatment; American Diabetes Association: Arlington County, VA, USA, 2017; (Suppl. 1), pp. S64-S74.

3. Chaudhury, A.; Duvoor, C.; Dendi, V.S.R.; Kraleti, S.; Chada, A.; Ravilla, R.; Marco, A.; Shekhawat, N.S.; Montales, M.T.; Kuriakose, K.; et al. Clinical review of antidiabetic drugs: Implications for type 2 diabetes mellitus management. Front. Endocrinol. 2017, 8, 6. [CrossRef]

4. Santisuk, T.; Larsen, K. Flora of Thailand Volume 10 Part 3 Anacardiaceae $\mathcal{E}$ Convolvulaceae; Prachachod Co. Ltd.: Bangkok, Thailand, 2010; pp. 440-450.

5. Art of Healing Division. General Ancient Medicine Textbook in Pharmaceutic; Ministry of Public Health: Bangkok, Thailand, 1998; p. 62.

6. Chayarop, K.; Peungvicha, P.; Temsiririrkkul, R.; Wongkrajang, Y.; Chuakul, W.; Rojsanga, P. Hypoglycaemic activity of Mathurameha, a Thai traditional herbal formula aqueous extract, and its effect on biochemical profiles of streptozotocinnicotinamide-induced diabetes rats. BMC Complement. Altern. Med. 2017, 17, 343. [CrossRef] [PubMed]

7. Satean, G.; Homhuan, S.; Premaprasit, S. Plant utilization from Thungluilai community forest in Thungluilai sub-district, Kornsarn distric t, Chaiyaphum province. J. Soc. Sci. Naresuan Univ. 2018, 19, 211-245.

8. Halabi, S.; Battah, A.A.; Aburjai, T.; Hudaib, M. Phytochemical and antiplatelet investigation of Gundelia tournifortii. Pharm. Biol. 2005, 43, 496-500. [CrossRef]

9. Costa, T.M.; Mayer, D.A.; Siebert, D.A.; Micke, G.A.; Alberton, M.D.; Tavares, L.B.B.; Oliveira, D. Kinetics analysis of the inhibitory effects of alpha-glucosidase and identification of compounds from Ganoderma lipsiense mycelium. Appl. Biochem. Biotechnol. 2020, 191, 996-1009. [CrossRef]

10. Mahomoodally, M.F.; Vlaisavljevic, S.; Berezni, S.; Abdallah, H.H.; Zengin, G.; Atanasov, A.G.; Mollica, A.; Lobine, D.; Aktumsek, A.; Abdurrahman, A. Lotus aegaeus (Gris.) Boiss and Iberis sempervirens L.: Chemical fingerprints, antioxidant potential, and inhibition activities and docking on key enzymes linked to global health problems. Ind. Crop Prod. 2018, 120, 271-278. [CrossRef]

11. Song, Y.H.; Kim, D.W.; Curtis-Long, M.J.; Park, C.; Son, M.; Kim, J.Y.; Yuk, H.J.; Lee, K.W.; Park, K.H. Cinnamic acid amides from Tribulus terrestris displaying uncompetitive $\alpha$-glucosidase inhibition. Eur. J. Med. Chem. 2016, 114, 201-208. [CrossRef] [PubMed]

12. Liu, X.; Luo, J.; Kong, L. Phenylethyl cinnamides as potential $\alpha$-glucosidase inhibitors from the roots of Solanum melongena. Nat. Prod. Commun. 2011, 6, 851-853. [CrossRef]

13. Panidthananon, W.; Chaowasku, T.; Sritularak, B.; Likhitwitayawuid, K. A new benzophenone C-glucoside and other constituents of Pseuduvaria fragrans and their $\alpha$-glucosidase inhibitory activity. Molecules 2018, 23, 1600. [CrossRef]

14. Islam, M.N.; Jung, H.A.; Sohn, H.S.; Kim, H.M.; Choi, J.S. Potent $\alpha$-glucosidase and protein tyrosine phosphatase 1Binhibitors from Artemisia capillaris. Arch. Pharm. Res. 2013, 36, 542-552. [CrossRef] [PubMed]

15. Tan, D.C.; Ku, I.I.; Nur, K.K.; Lima, P.C.; Ismaila, I.S.; Hamidb, M.; Nga, R.C. Comparative study of the antidiabetic potential of Paederia foetida twig extracts and compounds from two different locations in Malaysia. Pharm. Biol. 2019, 57, 345-354. [CrossRef] [PubMed]

16. Cheemanapalli, S.; Mopuri, R.; Golla, R.; Anurudha, C.M.; Chitta, S.K. Syringic acid (SA)—A review of its occurrence, biosynthesis, pharmacological and industrial importance. Biomed. Pharmacother. 2018, 108, 547-557.

17. Copeland, R.A. Reversible modes of inhibitor interactions with enzymes. In Evaluation of Enzyme Inhibitors in Drug Discovery: A Guide for Medicinal Chemists and Pharmacologists; John Wiley \& Sons: Hoboken, NJ, USA, 2005; pp. 48-81.

18. Jang, J.H.; Park, J.E.; Han, J.S. Scopoletin inhibits $\alpha$-glucosidase in vitro and alleviates postprandial hyperglycemia in mice with diabetes. Eur. J. Pharmacol. 2018, 834, 152-156. [CrossRef] [PubMed]

19. Zhang, L.; Bai, B.; Liu, X.; Wang, Y.; Li, M.; Zhao, D. $\alpha$-Glucosidase inhibitors from Chinese yam (Dioscorea opposite Thunb.). Food Chem. 2011, 126, 203-206. [CrossRef]

20. Wu, Q.; Yang, X.; Zou, L.; Fu, D. Bioactivity guided isolation of alpha-glucosidase inhibitor from whole herbs of Crossostephium chinense. Zhongguo Zhong Yao Za Zhi 2009, 34, 2206-2211. [PubMed]

21. Son, H.U.; Yoon, E.K.; Yoo, C.Y.; Park, C.H.; Bae, M.A.; Kim, T.H.; Lee, C.H.; Lee, K.W.; Seo, H.; Kim, K.J.; et al. Effects of synergistic inhibition on $\alpha$-glucosidase by phytoalexins in soybeans. Biomolecules 2019, 9, 828. [CrossRef] [PubMed]

22. Dej-adisai, S.; Pitakbut, T. Determination of $\alpha$-glucosidase inhibitory activity from selected Fabaceae plants. Pak. J. Pharm. Sci. 2015, 28, 1679-1683. 
23. Chetty, S.; Soliman, M.E.S. Possible allosteric binding site on Gyrase B, a key target for novel anti-TB drugs: Homology modelling and binding site identification using molecular dynamics simulation and binding free energy calculations. Med. Chem. Res. 2015, 24, 2055-2074. [CrossRef]

24. Hanwell, M.D.; Curtis, D.E.; Lonie, D.C.; Vandermeersch, T.; Zurek, E.; Hutchison, G.R. Avogadro: An advanced semantic chemical editor, visualization, and analysis platform. J. Cheminform. 2012, 4, 17. [CrossRef]

25. Morris, G.M.; Huey, R.; Lindstrom, W.; Sanner, M.F.; Belew, R.K.; Goodsell, D.S.; Olson, A.J. AutoDock4 and AutoDockTools4: Automated docking with selective receptor flexibility. J. Comput. Chem. 2009, 30, 2785-2791. [CrossRef]

26. Pettersen, E.F.; Goddard, T.D.; Huang, C.C.; Couch, G.S.; Greenblatt, D.M.; Meng, E.C.; Ferrin, T.E. UCSF Chimera-a visualization system for exploratory research and analysis. J. Comput. Chem. 2004, 25, 1605-1612. [CrossRef] [PubMed]

27. Dej-adisai, S.; Rais, I.R.; Wattanapiromsakul, C.; Pitakbut, T. Alpha-glucosidase inhibitory assay-screened isolation and molecular docking model from Bauhinia Pulla active compounds. Molecules 2021, 26, 5970. [CrossRef] [PubMed] 